\title{
CORRELATION AND REGRESSION ANALYSIS OF THE IMPACT OF LEASING ON AGRICULTURAL PRODUCTION IN REPUBLIC OF SERBIA
}

\author{
Marijana Joksimović ${ }^{\text {, Biljana Grujić }}{ }^{2}$, Dušan Joksimović ${ }^{3}$ \\ *Corresponding author E-mail: biljana_g@iep.bg.ac.rs
}

A R T I C L E I N F O
Original Article
Received: 12 March 2018
Accepted: 04 May 2018
doi:10.5937/ekoPolj1802583J
UDC 303:[339.187.6:338.432](497.11)

Keywords:

leasing, agriculture, correlation and regression analysis, agricultural goods

JEL: C4, C6, G2

\section{A B S T R A C T}

The paper explores the impact of leasing in agriculture on agricultural production in the Republic of Serbia by means of correlation and regression analysis. The research was conducted in the period between 2006 and 2016. The authorized data from National Bank of Serbia and Statistical Office of the Republic of Serbia were used in the paper. With the aim of carrying out a more comprehensive research, the paper analyzes the impact of leasing placement on the following economic accounts for agriculture: Output of agricultural industry, Intermediate consumption, Gross value added, Agricultural goods output, and Factor income.

(C) 2018 EA. All rights reserved.

\section{Introduction}

Numerous authors have dealt with the definition of agriculture, its divisions and interpretations. Bogdanović (1967) divides agriculture into a) agro-technical and economic; b) extensive and intensive. There is also an interpretation of agriculture in its narrower and broader sense (Radović, 2014). Agriculture in its narrower sense involves agricultural production for one's own needs, while agriculture in its broader sense implies horizontal and vertical connection of economic fields and industries. Agricultural production interconnected in this way is commonly known as agroindustrial complex (the term is used in domestic and Eastern-European literature) or agro-business (which is the term used in Western-European literature).

Leasing, as one of potential methods of financing agriculture, represents a form of business deal whereby a leasing provider gives the leasing recipient a particular object to use, under the condition of payment of the agreed amount of money in the form of installments. The leasing provider has the ownership over the object of the leasing until

1 Marijana Joksimović, Ph.D., Associate Professor, Megatrend University, Belgrade, Serbia, e-mail: joksimovicm@megatrend.edu.rs

2 Biljana Grujić, Ph.D., Research assistant, Institute of Agricultural Economics, Belgrade, Serbia, e-mail: biljana_g@iep.bg.ac.rs

3 Dušan Joksimović, Full Professor, The Academy of Criminalistic and Police Studies, Belgrade, Serbia, e-mail: dusan.joksimovic@kpa.edu.rs 
it is paid off (Paraušić, Cvijanović, 2007). Leasing, as a modern method of financing, was first used in the 50s of the 20th century in the US. On the territory of Republic of Serbia, the financial leasing business is legally regulated by The Law on Financial Leasing (The Official Gazette no. 55/2003) adopted in May 2003, and its amendment from 2005 (The Official Gazette no. 61/2005). National Bank of Serbia supervises the operations of financial leasing providers and undertakes corrective measures. The applicable law that is still in force today is the Law on Financial Leasing (The Official Gazette of RS no. 55/2003, 61/2005, 31/2011, 99/2011 etc.).

Although leasing market is not sufficiently represented and developed in Serbia, this sector still occupies an increasingly important place in financing agriculture. It can be said that leasing in the procurement of equipment and machinery for the needs of agricultural production has been sufficiently accepted by farmers. Their increasing awareness and education certainly contribute to that fact. In that way they can take full advantage of leasing benefits compared with traditional crediting, with the benefits referring primarily to a lower interest rate (Grujić, 2017).

Foreign economists' body of research (Brealey et al., 2001) points to three types of leasing:

- direct leasing when a company buys goods from manufacturers;

- operational leasing creates the responsibility of the object of leasing maintenance by the leasing provider, who is responsible for taxes and insurance; the leasing provider has the right to cancel the leasing before the expiry of the agreed date and the leasing recipient returns the object of the lease and ceases to repay the installments;

- financial leasing, which implies that the leasing recipient bears the costs of taxation, insurance and damage; leasing cannot be cancelled, but in case of cancellation the leasing recipient is obliged to pay the penalties and settle obligations arising from leasing.

The paper analyzes the impact of financial leasing. There are 16 registered institutions in the Republic of Serbia that operate as leasing providers. All these institutions place their assets into leasing in agriculture as well. Analyzing the period from 2006 to 2016, the impact of leasing was examined on the following economic accounts for agriculture: Output of agricultural industry, Intermediate consumption, Gross value added, Agricultural goods output, and Factor income.

\section{The Methodology of the applied analysis}

The paper analyzes the cumulative impact of leasing placement in agriculture in the period from 2006 to 2015 on the trends of certain Economic Accounts for Agriculture (EAA) in the period from 2007 to 2016.

The cumulative impact of the leasing placement in Agriculture, forestry and fishing sector and the cumulative impact of leasing placement in Agricultural equipment in 
the given period were analyzed in parallel. Data on annual leasing placements were taken from the annual reports of the Department for supervision of financial leasing operations, and the Department for supervision of operations of banks of National Bank of Serbia. The used data are available on the National Bank of Serbia official website (NBS, 2006-2016).

The leasing placement is analyzed in the following Economic Accounts for Agriculture: Output of agricultural industry, Intermediate consumption, Gross value added, Agricultural goods output and Factor income ${ }^{4}$.

The reason for the selection of the mentioned economic accounts for agriculture lies in the fact that they can help examine the impact of the cumulative leasing placement on the volume of produced agricultural goods (in the form of impact on the Output of agricultural industry and on the Agricultural goods output), on the volume of costs during total agricultural production (in the form of the impact on Intermediate consumption) and on the volume of profit before taxation and subsidies (in the form of impact on Gross value added) and after taxation and subsidies (in the form of impact on Factor income).

Data on the aforementioned economic accounts for agriculture were taken from the working document entitled Economic Accounts for Agriculture in RS 2007-2016 (SORS, 2017).

Changes in the volume of these economic accounts for agriculture outputs were analyzed, depending on the cumulative leasing placement in agriculture. These economic accounts are presented in this document in the form of a Laspeyres Index, with weights from the previous year. The series weighted in this way cannot be used to calculate real growth, because the data by years are not comparable. In order to obtain a series of comparable data, a chain-linking method is used, whereby data is reduced to one reference year, thus obtaining a comparable time series of data which correctly represents the value change in the volume of interest. This is how the chain-linked measures of volume are obtained. According to Eurostat recommendations, the year of 2010 is taken as a reference year.

Such chain-linked data (SORS, 2017) are significant for the Output of agricultural industry, Intermediate consumption and Gross value added, while the cross-linked data for the Agricultural goods output and Factor income are interpolated, assuming that their chain-linking is proportional to chain-linking of the Output of agricultural industry.

4 Output of agricultural industry is equal to the sum of the value of crop production, animal production, agricultural services and value of production from inseparable non-agricultural secondary activities on the holdings. Intermediate consumption is the value of all goods and services used as inputs in the agricultural production process. It is valued at the purchaser prices. Gross value added at basic prices is equal to the difference between the value of agricultural production (output of the agricultural 'industry') at basic prices and intermediate consumption at purchaser prices. Agricultural goods output is the value of production of all agricultural goods (crop and animal production). Factor income is equal to the difference between net value added at basic prices and consumption of fixed capital less taxes on production, plus subsidies on production (SORS, 2017). 
Regardless of the fact that this is not exactly the exact reduction to their weight from 2010, it was assumed that for this type of analysis the correction was negligible, which, as it will be shown, will not be denied by the results. The interpolation was performed because the cross-linked data for the Agricultural goods output and Factor income did not exist in the above mentioned working document.

The cumulative impact of leasing placement in agriculture on the above-mentioned Economic accounts for agriculture was analyzed by means of correlation and regression analysis. Namely, the correlation and regression dependence of the given accounts in agriculture in the $i$-th year $(i=2007,2008, \ldots, 2016)$ was found on the sum of the placed leased assets in agriculture from 2006 to (i-1) year, since it can be expected, for example, that the sum of all placed leased assets in agriculture from 2006-2013 should influence, to some extent, the produced agricultural goods output in 2014. This influence, if any, is not large, primarily for two reasons. The first is that agricultural activity in our country has for years been of similar characteristics in a macro sense and that it has mostly depended on climatic conditions. The second is that the amount of leased assets in agriculture in the period 2006-2015 was low compared to intermediate consumption in the process of agricultural production. At the annual level, the leased assets in agriculture are somewhere around 3-5\% of the intermediate annual consumption in agriculture (see Table 1 and Table 2).

\section{Tabular and graphical representation of used data}

In Table 1 the chain-linked values of the analyzed economic accounts for agriculture are given in million RSD, in the period 2007-2016 on the territory of the Republic of Serbia. The base year is 2010 .

Table 1. Chain-linked values for the base year of 2010 in mil. RSD

\begin{tabular}{|c|c|c|c|c|c|}
\hline Year & $\begin{array}{c}\text { Output of agricultural } \\
\text { industry }\end{array}$ & $\begin{array}{c}\text { Intermediate } \\
\text { consumption }\end{array}$ & $\begin{array}{c}\text { Gross value } \\
\text { added }\end{array}$ & $\begin{array}{c}\text { Agricultural goods } \\
\text { output }\end{array}$ & Factor income \\
\hline 2007 & $432,951.8$ & $251,217.3$ & $182,960.3$ & $384,831.2$ & $158,072.4$ \\
\hline 2008 & $473,449.9$ & $273,818.8$ & $201,006.2$ & 428,613 & $197,108.2$ \\
\hline 2009 & $491,734.7$ & $278,449.4$ & $214,477.9$ & $442,993.5$ & $184,050.7$ \\
\hline 2010 & $498,776.4$ & $295,276.6$ & $203,499.7$ & $455,752.7$ & $186,000.4$ \\
\hline 2011 & $505,305.7$ & $292,802.2$ & $212,503.5$ & $456,046.5$ & $189,443.3$ \\
\hline 2012 & $420,630.7$ & $269,271.2$ & $152,184.7$ & $380,868.3$ & $160,462.7$ \\
\hline 2013 & $492,445.4$ & $289,411.1$ & $198,120.5$ & $436,462.8$ & $185,424.7$ \\
\hline 2014 & $538,643.2$ & $316,582.3$ & 216,687 & $478,444.1$ & $203,726.2$ \\
\hline 2015 & $506,934.7$ & $294,041.8$ & $207,749.2$ & $448,409.5$ & $196,448.8$ \\
\hline 2016 & $554,376.5$ & $319,362.9$ & $229,409.1$ & 492,031 & 210,947 \\
\hline
\end{tabular}

Source: The authors' research based on Economic Accounts in Agriculture in 2007-2016

Table 1 points to the well-known fact that the negative impact of bad climate conditions in 2012 was crucial for the reduced volume of agricultural goods production in that year. Therefore, in addition to the complete time series, the analysis was also conducted for the time series excluding the values of the Economic accounts for agriculture in 2012, 
since without the data from that year, the sensitivity of the change of the Economic accounts for agriculture from the cumulative value of leasing in agriculture is higher.

The following Table 2 contains the annual and cumulative values of leasing assets placement in two agricultural categories on the territory of the Republic of Serbia.

Table 2. Annual and cumulative leasing placement in mil. RSD

\begin{tabular}{|c|r|r|r|r|}
\hline Year & $\begin{array}{c}\text { Annual leasing } \\
\text { placement in } \\
\text { Agriculture, forestry } \\
\text { and fisheries sector }\end{array}$ & $\begin{array}{l}\text { Cumulative leasing placement } \\
\text { in Agriculture, forestry and } \\
\text { fisheries sector }\end{array}$ & $\begin{array}{c}\text { Annual leasing } \\
\text { placement in } \\
\text { Agricultural } \\
\text { equipment }\end{array}$ & $\begin{array}{c}\text { Cumulative } \\
\text { leasing placement } \\
\text { in Agricultural } \\
\text { equipment }\end{array}$ \\
\hline 2006 & $8,530.5$ & $8,530.5$ & $7,379.6$ & $7,379.6$ \\
\hline 2007 & $11,241.3$ & $19,771.8$ & $8,764.3$ & $16,143.9$ \\
\hline 2008 & $16,421.8$ & $36,193.6$ & $10,171.7$ & $26,315.6$ \\
\hline 2009 & $14,470.8$ & $50,664.4$ & $8,682.5$ & $34,998.1$ \\
\hline 2010 & $8,005.6$ & 58,670 & $6,720.7$ & $41,718.8$ \\
\hline 2011 & $5,133.7$ & $63,803.7$ & $5,133.7$ & $46,852.5$ \\
\hline 2012 & $5,039.1$ & $68,842.8$ & $6,550.9$ & $53,403.4$ \\
\hline 2013 & $6,071.6$ & $74,914.4$ & $5,869.2$ & $59,272.6$ \\
\hline 2014 & $6,347.6$ & 81,262 & $6,413.1$ & $65,685.7$ \\
\hline 2015 & $4,760.9$ & $86,022.9$ & $5,484.1$ & $71,169.8$ \\
\hline
\end{tabular}

Source: The authors' research based on SORS and NBS data

The first category involves leasing placement in Agriculture, forestry and Fisheries sector, while the second refers to leasing placement in Agricultural equipment in the period 2006-2015. The data shown are in mil. RSD. The analysis was conducted for both categories of leasing assets investment, regardless of the fact that these categories are largely intertwined, in order to verify more effectively the existence of the impact of leasing placement in agriculture on the volume of produced agricultural goods.

\section{The results of regression and correlation analysis}

The correlation and regression analysis of the dependence of the volume of the above mentioned agricultural accounts on the cumulative leasing placement into Agriculture, forestry and fisheries sector, and on the leasing placement into Agricultural equipment, was conducted by means of MATLAB software package. The dependence for the period 2007-2016 was obtained in two ways.

The first one includes all the data of the Economic accounts and the cumulative leasing placement in that period, and the second one the situation excluding all data from 2012, because that was extremely bad year for the production of agricultural goods, mostly due to very poor climatic conditions. Of course, for the cumulative leasing values for 2013, the values of leasing placement in 2012 were still used.

In both cases, the dependence of change is highly linear, so that a simple linear regression analysis is applied everywhere. 


\section{-The dependence of Output of agricultural industry on cumulative leasing placement}

Simple linear regression dependence of Output of agricultural industry on Cumulative leasing placement into the Agriculture, forestry and fisheries sector equals:

\section{-all data from the series}

Output of agricultural industry $($ mil. RSD $)=0.9201 *$ Cumulative leasing $($ mil.RSD $)+$ $4.371 * 10^{5}$ with determination coefficient $\boldsymbol{R}^{2}=0.389$ and with $\boldsymbol{p}$ value being $\boldsymbol{p}=0.0539$ (see Figure 1).

\section{- excluding data from 2012}

Output of agricultural industry $($ mil. RSD) $=1.1237 *$ Cumulative leasing (mil.RSD) $+4.3886 * 10^{5}$ with determination coefficient $\boldsymbol{R}^{2}=0.771$ and with $\boldsymbol{p}$ value being $\boldsymbol{p}=$ 0.00185 (see Figure 2).

Figure 1. With data from 2012

Figure 2. Excluding data from 2012
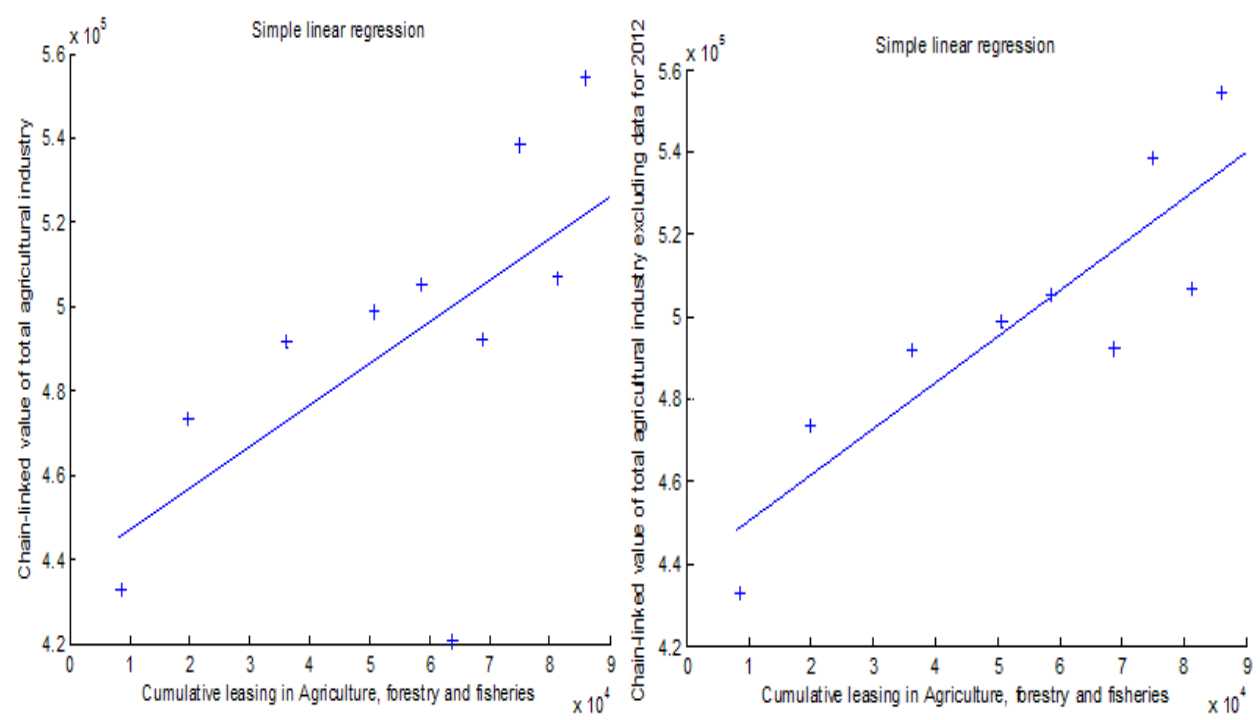

Source: The authors' research (MATLAB software package)

Simple linear regression dependence of Output of agricultural industry on Cumulative leasing placement into Agricultural equipment equals:

\section{- all data from the series}

Output of agricultural industry (mil. RSD) $=1.271 *$ Cumulative leasing (mil.RSD) $+4.3777 * 10^{5}$ with determination coefficient $\boldsymbol{R}^{2}=0.421$ and with $\boldsymbol{p}$ value being $\boldsymbol{p}=$ 0.0423(see Figure3).

\section{-excluding data from 2012}


Output of agricultural industry $($ mil. RSD) $=1.368 *$ Cumulative leasing (mil.RSD) $+4.4223 * 10^{5}$ with determination coefficient $\boldsymbol{R}^{2}=0.76$ and with $\boldsymbol{p}$ value being $\boldsymbol{p}=$ 0.00218 (see Figure 4).

Figure 3. With data from 2012

Figure 4. Excluding data from 2012
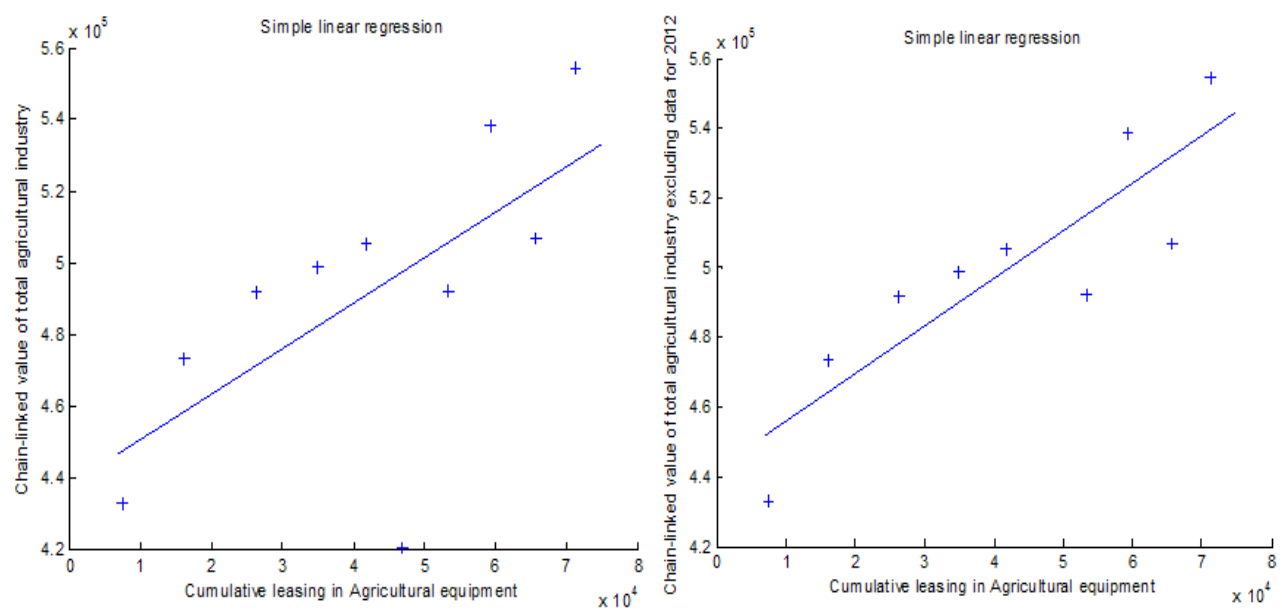

Source: The authors' research (MATLAB software package)

\section{-The dependence of Intermediate consumption on Cumulative leasing placement}

Simple linear regression dependence of Intermediate consumption on Cumulative leasing placement into Agriculture, forestry and fishing industries equals:

\section{-all data from the series}

Intermediate consumption (mil. RSD) $=0.644 *$ Cumulative leasing (mil. RSD) $+2.527 * 10^{5}$ with determination coefficient $\boldsymbol{R}^{2}=0.647$ and with $\boldsymbol{p}$ value being $\boldsymbol{p}=0.00503$ (see Figure 5).

\section{- excluding data from 2012}

Intermediate consumption (mil. RSD) $=0.6843 *$ Cumulative leasing (mil. RSD) $+2.5324 * 10^{5}$ with determination coefficient $\boldsymbol{R}^{2}=0.8$ and with $\boldsymbol{p}$ value being $\boldsymbol{p}=0.00113$ (see Figure 6). 
Figure 5. With data from 2012

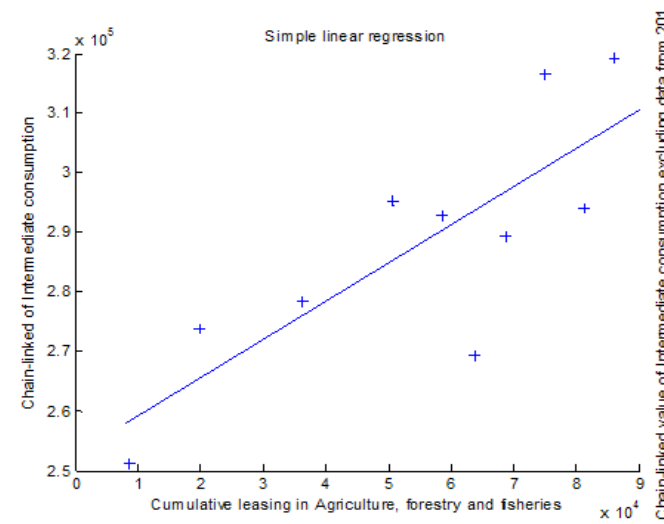

Figure 6. Excluding data from 2012

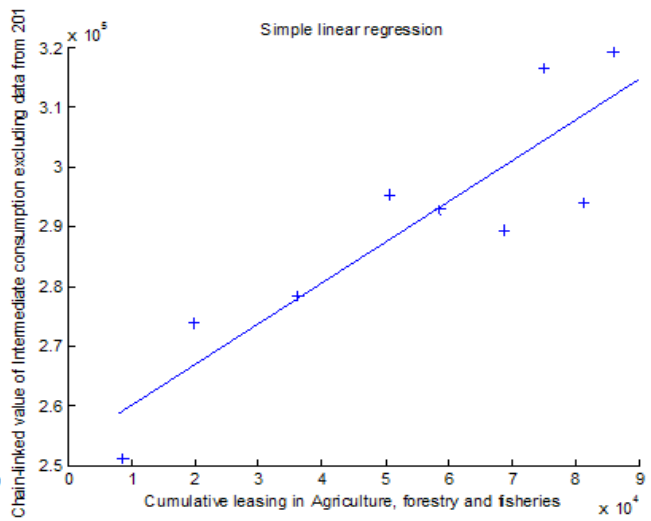

Source: The authors' research (MATLAB software package)

Simple linear regression dependence of Intermediate consumption on Cumulative leasing placement into Agricultural equipment equals:

\section{-all data from the series}

Intermediate consumption (mil. RSD) $=0.799 *$ Cumulative leasing(mil. RSD) $+2.5425 * 10^{5}$ with determination coefficient $\boldsymbol{R}^{2}=0.656$ and with $\boldsymbol{p}$ value being $\boldsymbol{p}=0.00449$.(see Figure 7).

\section{- excluding data from 2012}

Intermediate consumption (mil. RSD) $=0.827 *$ Cumulative leasing(mil. RSD) $+2.555^{*} 10^{5}$ with determination coefficient $\boldsymbol{R}^{2}=0.777$ and with $\boldsymbol{p}$ value being $\boldsymbol{p}=0.00167$ (see Figure 8).

Figure 7. With data from 2012

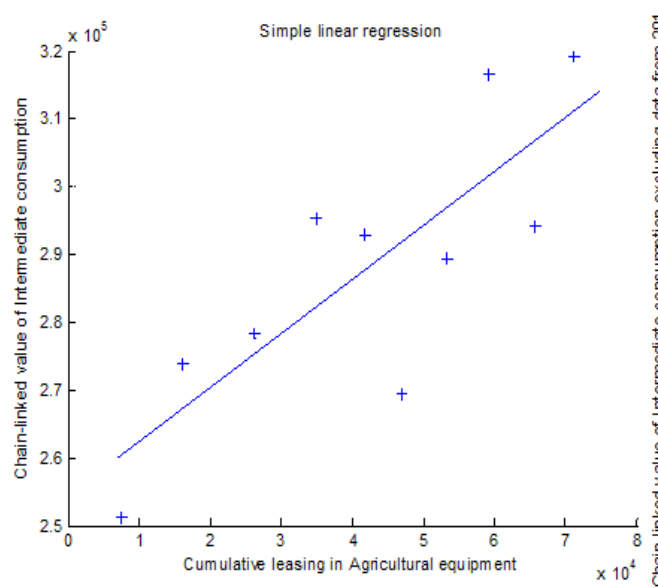

Figure 8. Excluding data from 2012

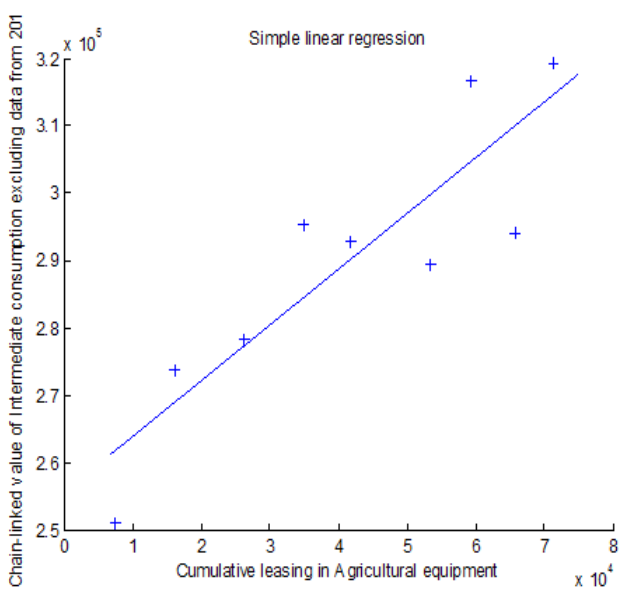

Source: The authors' research (MATLAB software package) 


\section{-The dependence of the value of Gross value added on Cumulative leasing placement}

Simple linear regression dependence of Gross value added on Cumulative leasing placement into Agriculture, forestry and fishing industries equals:

\section{-all data from the series}

Gross value added (mil. RSD) $=0.249 *$ Cumulative leasing (mil.RSD) $+1.8821 * 10^{5}$ with determination coefficient $\boldsymbol{R}^{2}=0.0915$ and with $\boldsymbol{p}$ value being $\boldsymbol{p}=0.396$ (see Figure 9).

\section{- excluding data from 2012}

Gross value added $($ mil. RSD $)=0.3344 *$ Cumulative leasing $($ mil.RSD $)+1.8936 * 10^{5}$ with determination coefficient $\boldsymbol{R}^{2}=0.485$ and with $\boldsymbol{p}$ value being $\boldsymbol{p}=0.0371$ (see Figure 10).

Figure 9. With data from 2012

Figure 10. Excluding data from 2012
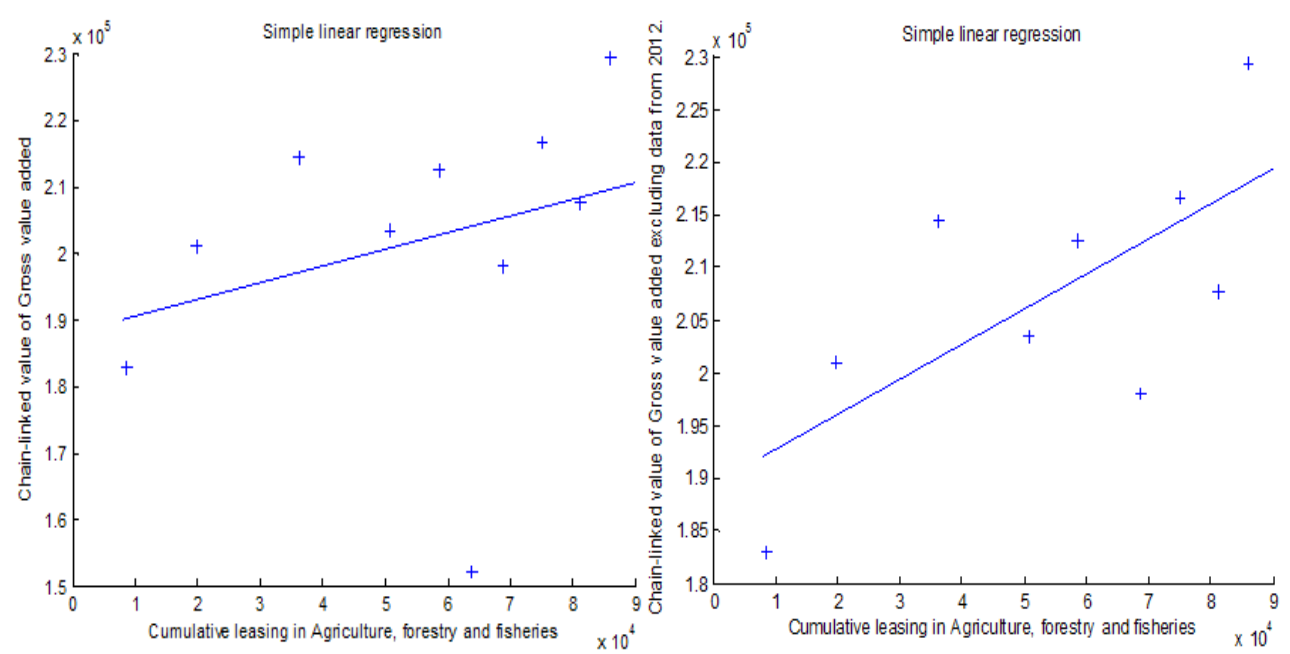

Source: The authors' research (MATLAB software package)

Simple linear regression dependence of Gross value added on Cumulative leasing placement in Agricultural equipment equals:

\section{-all data from the series}

Gross value added (mil. RSD) $=0.343 *$ Cumulative leasing (mil.RSD) $+1.8736 * 10^{5}$ with determination coefficient $\boldsymbol{R}^{2}=0.115$ and with $\boldsymbol{p}$ value being $\boldsymbol{p}=0.339$ (see Figure 11).

-excluding data from 2012

Gross value added (mil. RSD) $=0.408 *$ Cumulative leasing (mil.RSD) $+1.9035 * 10^{5}$ with determination coefficient $\boldsymbol{R}^{2}=0.48$ and with $\boldsymbol{p}$ value being $\boldsymbol{p}=0.0387$ (see Figure 12). 
Figure 11. With data from 2012

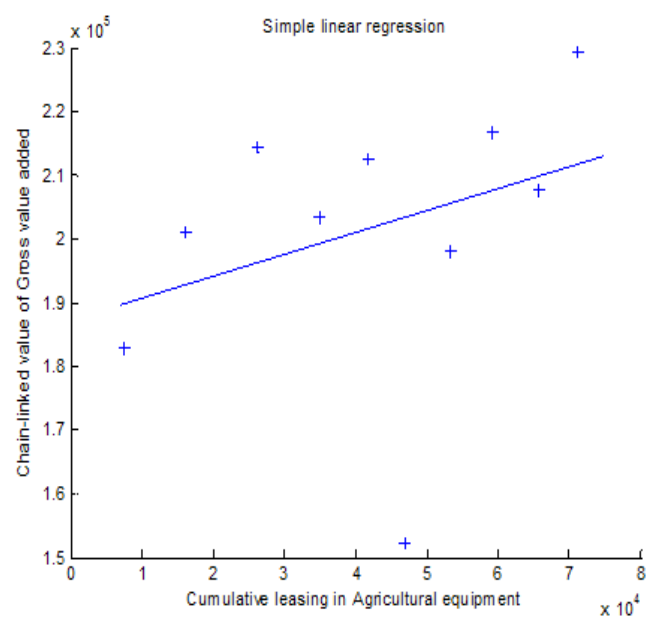

Figure 12. Excluding data from 2012

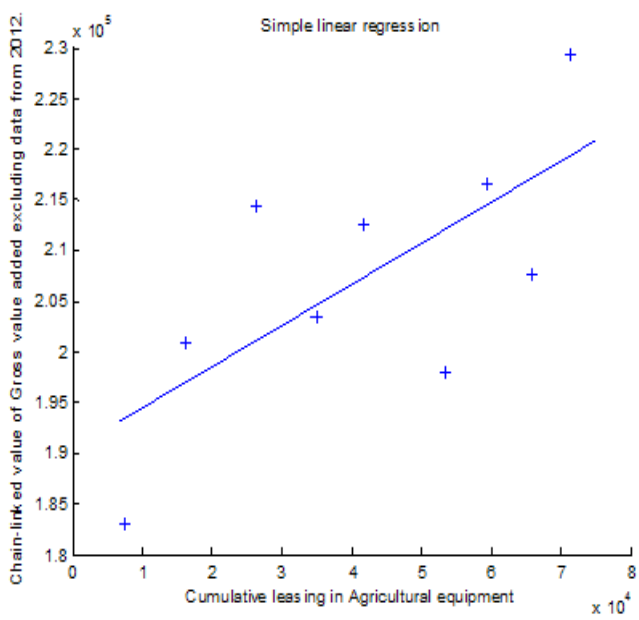

Source: The authors' research (MATLAB software package)

\section{-The dependence of the value of Total agricultural goods output on Cumulative leasing placement}

Simple linear regression dependence of Total agricultural goods output on Cumulative leasing placement into Agriculture, forestry and fishing industries equals:

-all data from the series

Agricultural goods output $($ mil. RSD) $=0.808 *$ Cumulative leasing $($ mil.RSD $)+3.9612 *$ $10^{5}$ with determination coefficient $\boldsymbol{R}^{2}=0.348$ and with $\boldsymbol{p}$ value being $\boldsymbol{p}=0.0727$ (see Figure 13).

-without data from 2012

Agricultural goods output $($ mil. RSD $)=0.918 *$ Cumulative leasing $($ mil.RSD $)+3.9761$ * $10^{5}$ with determination coefficient $\boldsymbol{R}^{2}=0.675$ and with $\boldsymbol{p}$ value being $\boldsymbol{p}=0.00658$ (see Figure 14). 
Figure 13. With data from 2012

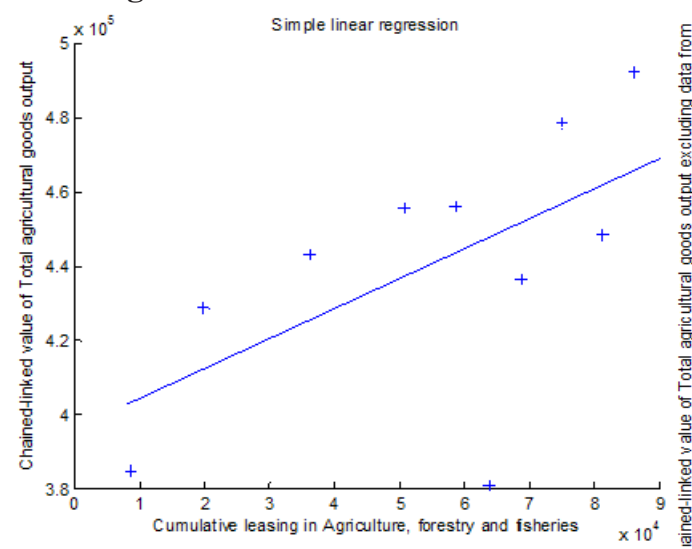

Figure14. Excluding data from 2012

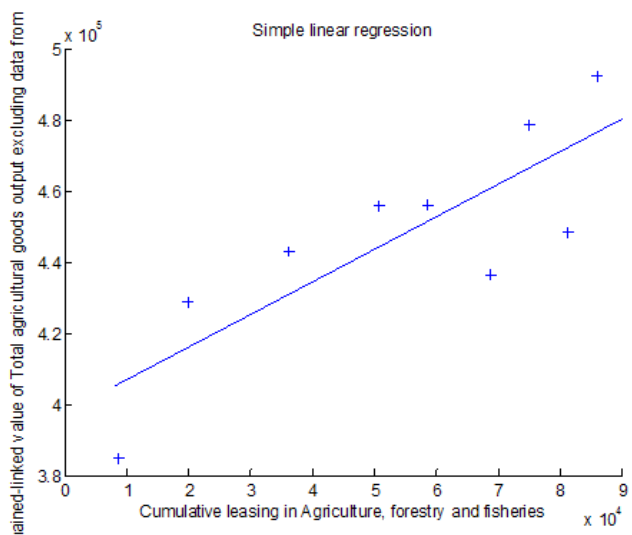

Source: The authors' research (MATLAB software package)

Simple linear regression dependence of Total agricultural goods output on Cumulative leasing placement into Agricultural equipment equals:

\section{-all data from the series}

Agricultural goods output $($ mil. RSD) $=1.017 *$ Cumulative leasing (mil.RSD) + $3.9742 * 10^{5}$ with determination coefficient $\boldsymbol{R}^{2}=0.364$ and with $\boldsymbol{p}$ value being $\boldsymbol{p}=0.0649$ (see Figure 15).

\section{-excluding data from 2012}

Agricultural goods output (mil. RSD) $=1.0986 *$ Cumulative leasing (mil.RSD) + $4.0116 * 10^{5}$ with determination coefficient $\boldsymbol{R}^{2}=0.643$ and with $\boldsymbol{p}$ value being $\boldsymbol{p}=0.00929$ (see Figure 16).

Figure 15. With data from 2012

Figure 16. Excluding data from 2012
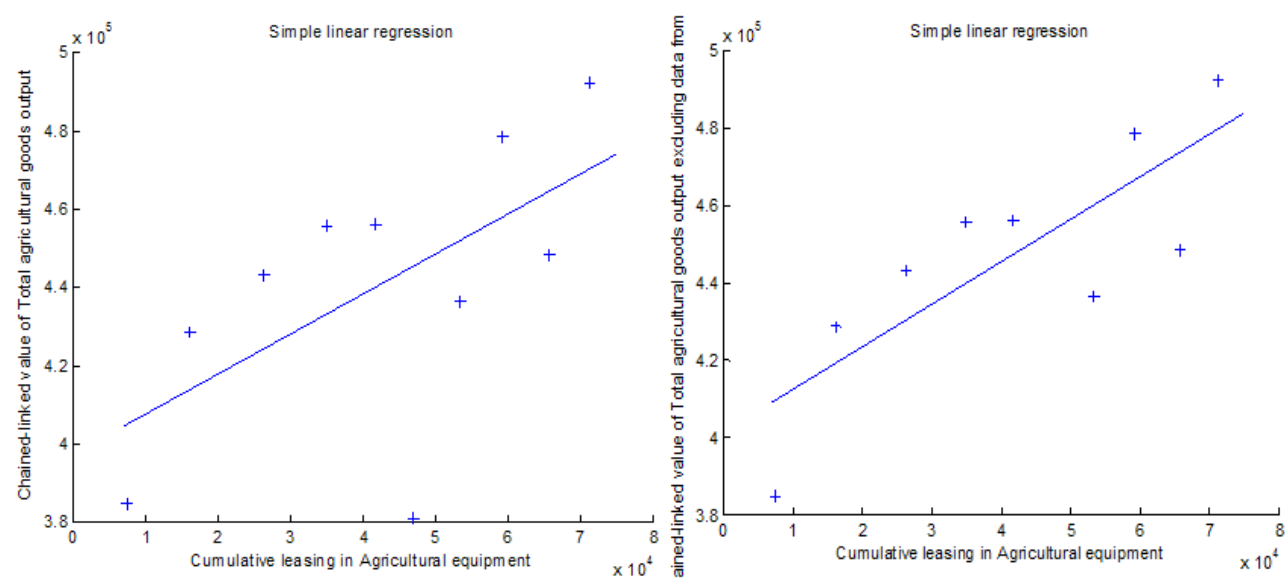

Source: The authors' research (MATLAB software package) 


\section{-The dependence of Factor income value on Cumulative leasing placement}

Simple linear regression of Factor income on Cumulative leasing placement into Agriculture, forestry and fisheries sector equals:

\section{-all data from the series}

Factor income $\left(\right.$ mil. RSD) $=0.348 *$ Cumulative leasing $($ mil.RSD $)+1.6806 * 10^{5}$ with determination coefficient $\boldsymbol{R}^{2}=0.284$ and with $\boldsymbol{p}$ value being $\boldsymbol{p}=0.112$ (see Figure 17).

\section{-excluding data from 2012}

Factor income $\left(\right.$ mil. RSD) $=0.397 *$ Cumulative leasing $($ mil.RSD $)+1.6872 * 10^{5}$ with determination coefficient $\boldsymbol{R}^{2}=0.525$ and with $\boldsymbol{p}$ value being $\boldsymbol{p}=0.0273$ (see Figure 18).

Figure 17. With data from 2012

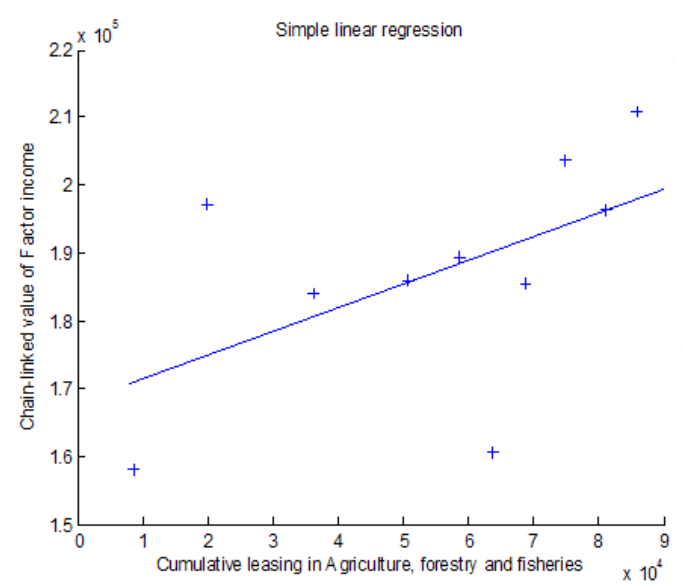

Figure 18. Excluding data from 2012

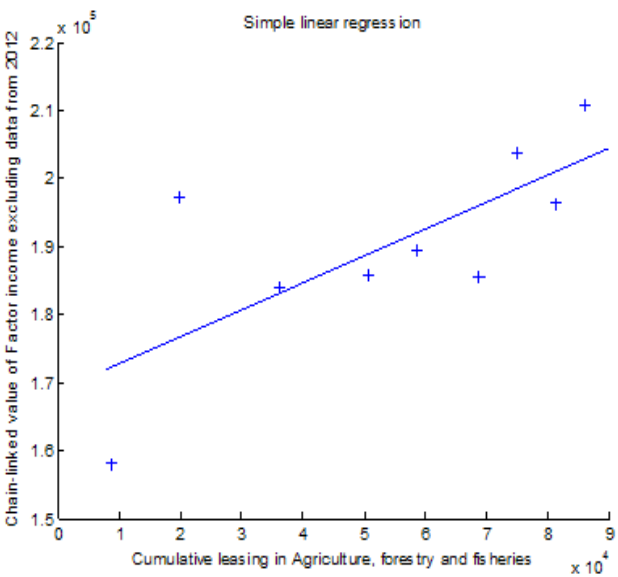

Source: The authors' research (MATLAB software package)

Simple linear regression dependence of Factor income on Cumulative leasing placement in Agricultural equipment equals:

\section{-all data from the series}

Factor income $($ mil. $\mathrm{RSD})=0.461 *$ Cumulative leasing $\left(\right.$ mil.RSD) $+1.6766 * 10^{5}$ with determination coefficient $\boldsymbol{R}^{2}=0.329$ and with $\boldsymbol{p}$ value being $\boldsymbol{p}=0.083$ (see Figure 19).

-excluding data from 2012

Factor income (mil. RSD) $=0.498 *$ Cumulative leasing (mil.RSD) $+1.6934 * 10^{5}$ with determination coefficient $\boldsymbol{R}^{2}=0.547$ and with $\boldsymbol{p}$ value being $\boldsymbol{p}=0.0227$ (see Figure 20). 
Figure 19. With data from 2012

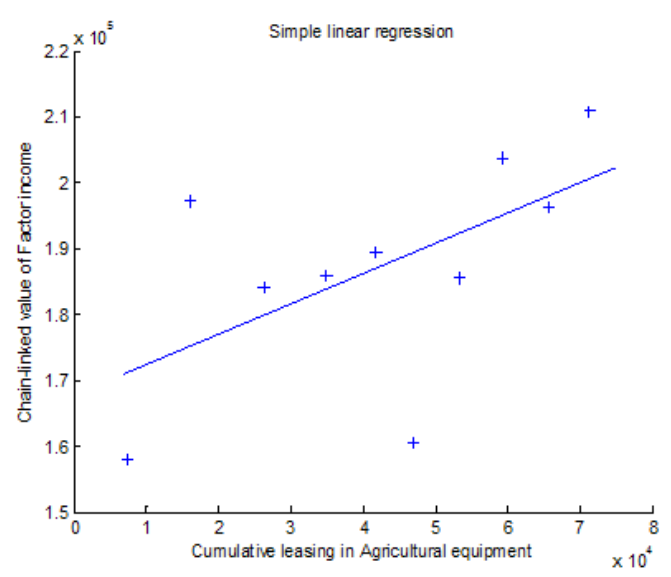

Figure 20. Excluding data from 2012

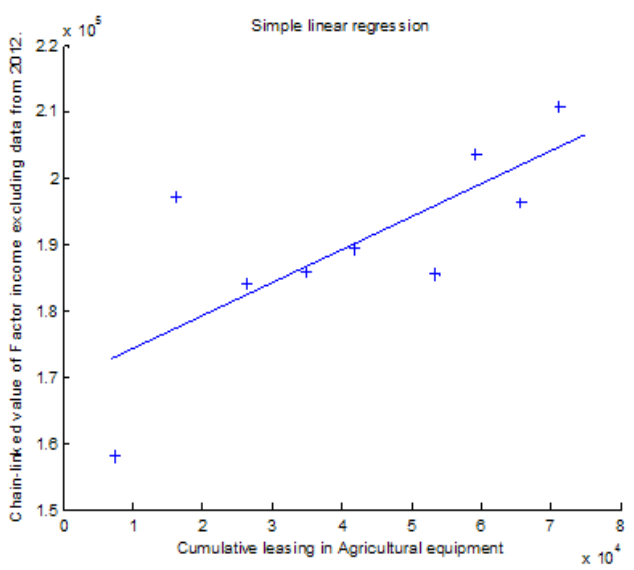

Source: The authors' research (MATLAB software package)

\section{The analysis of the obtained results}

As already mentioned, leasing placement into agriculture at the annual level is around $3-5 \%$ of Intermediate annual consumption in agriculture. The total ten-year cumulative leasing placement (2006-2015) in Agriculture, Forestry and Fisheries sector is $29.13 \%$ of the Intermediate annual consumption only in 2010. As for the placement in Agricultural equipment, this percentage is $24.10 \%$ (see Table 1 and Table 2).

Therefore, one should not expect large influence of leasing on the absolute values of agricultural outputs, as they are mostly determined by agricultural capacities in the Republic of Serbia and climatic conditions during the current year. Therefore, the value of the constant in all obtained regression dependencies is (about 10 times) bigger than the value of the variable member. The constant is, roughly speaking, the measure of agricultural potential and climatic conditions, while the variable is the measure of the impact of cumulative leasing on agricultural outputs.

The impact of cumulative leasing in agriculture on the volume of agricultural production was analyzed by means of its impact on the output of agricultural industry and on the total agricultural goods output from 2007-2016. In that period, the output of agricultural industry increased by $28.05 \%$, and the total agricultural goods output by $27.86 \%$.

Table 3 shows the parameters of regression analysis for the Output of agricultural industry and for the Total agricultural goods output. 
Table 3. The parameters of regression analysis for the Output of agricultural industry and for the Total agricultural goods output

\begin{tabular}{|c|c|c|c|c|c|c|c|c|}
\hline \multirow{3}{*}{$\begin{array}{c}\text { The } \\
\text { parameters } \\
\text { of } \\
\text { regression } \\
\text { analysis }\end{array}$} & \multicolumn{4}{|c|}{ The output of agricultural industry } & \multicolumn{4}{|c|}{ Total agricultural goods output } \\
\hline & \multicolumn{2}{|c|}{$\begin{array}{l}\text { Data from all years in the } \\
\text { period 2007-2016 }\end{array}$} & \multicolumn{2}{|c|}{ Excluding data from 2012} & \multicolumn{2}{|c|}{$\begin{array}{l}\text { Data from all years in the } \\
\text { period 2007-2016 }\end{array}$} & \multicolumn{2}{|c|}{ Excluding data from 2012} \\
\hline & $\begin{array}{l}\text { Cumulative } \\
\text { leasing in } \\
\text { Agriculture, } \\
\text { Forestry } \\
\text { and fisheries } \\
\text { sector }\end{array}$ & $\begin{array}{l}\text { Cumulative } \\
\text { leasing in } \\
\text { Agricultural } \\
\text { equipment }\end{array}$ & $\begin{array}{c}\text { Cumulative } \\
\text { leasing into } \\
\text { Agriculture, } \\
\text { Forestry } \\
\text { and fisheries } \\
\text { sector }\end{array}$ & $\begin{array}{l}\text { Cumulative } \\
\text { leasing in } \\
\text { Agricultural } \\
\text { equipment }\end{array}$ & $\begin{array}{c}\text { Cumulative } \\
\text { leasing in } \\
\text { Agriculture, } \\
\text { Forestry } \\
\text { and fisheries } \\
\text { sector }\end{array}$ & $\begin{array}{l}\text { Cumulative } \\
\text { leasing in } \\
\text { Agricultural } \\
\text { equipment }\end{array}$ & $\begin{array}{c}\text { Cumulative } \\
\text { leasing in } \\
\text { Agriculture, } \\
\text { Forestry } \\
\text { and fisheries } \\
\text { sector }\end{array}$ & $\begin{array}{l}\text { Cumulative } \\
\text { leasing in } \\
\text { Agricultural } \\
\text { equipment }\end{array}$ \\
\hline p-value & 0.0539 & 0.0423 & 0.00185 & 0.00218 & 0.0727 & 0.0649 & 0.00658 & 0.00929 \\
\hline \begin{tabular}{|l|} 
Determination \\
coefficient $\mathrm{R}^{2}$ \\
\end{tabular} & 0.389 & 0.421 & 0.771 & 0.76 & 0.348 & 0.364 & 0.675 & 0.643 \\
\hline
\end{tabular}

Source: Authors' research

By analyzing the obtained results and p-values from Table 3 it can be concluded that the dependence of the change in the Output of agricultural industry and Total agricultural goods output on Cumulative leasing into the Agriculture, forestry and fisheries sector and on Cumulative leasing in Agricultural equipment is subject to the law of positive linear regression. In addition, a more credible linear dependence is obtained if the analysis does not include data for the year in which the climatic conditions were predominantly bad for agricultural output (2012), than when they are used in the analysis.

In fact, p-values excluding data from 2012 are $0.00185,0.00218,0.00658$, and 0.0092 , in which case linear regression dependence describes changes with a probability higher than 0.99 , which is absolutely acceptable, while p-values including data from 2012 are $0.0539,0.0423,0.0727,0.0649$, and then linear regression dependence describes changes with probabilities from 0.927 to 0.957 , which is on the verge of acceptability.

In the case when the data from 2012 were used, when the climatic conditions were predominantly bad, the change in the Output of agricultural industry and Total agricultural goods output, depending on Cumulative leasing in agriculture, is not high. More precisely, in that case about $40 \%$ of the change in the Output of agricultural industry is described by the obtained positive linear regression dependence, since the determination coefficients R2 are equal to 0.389 and 0.421 , while about $35 \%$ of the change in Total agricultural goods output is described by the obtained positive linear regression dependence, with the determination coefficients R2 being 0.348 and 0.364 .

When data from 2012 are excluded, significant impact of Cumulative leasing in agriculture is detected on the change in Output of agricultural industry and Total agricultural goods output. In that case about $76.5 \%$ of the change in the Output of agricultural industry is described by the obtained positive linear-regression dependence, since the determination coefficients $\mathrm{R}^{2}$ are equal to 0.771 and 0.76 , while about $66 \%$ of the change in Total agricultural goods output is described by the obtained positive linear-regression dependence, with the determination coefficients $\mathrm{R}^{2}$ being 0.675 and 0.643 . 
The impact of Cumulative leasing in agriculture on the volume of costs during total agricultural goods output was analyzed by means of its impact on Intermediate consumption in the period from 2007 to 2016. During this period, the Intermediate consumption increased by $27.13 \%$. Table 4 shows the parameters for regression analysis for Intermediate consumption.

Table 4. The parameters for regression analysis for Intermediate consumption

\begin{tabular}{|c|c|c|c|c|}
\hline \multirow[b]{3}{*}{$\begin{array}{l}\text { The parameters of } \\
\text { regression analysis }\end{array}$} & \multicolumn{4}{|c|}{ Intermediate consumption } \\
\hline & \multicolumn{2}{|c|}{ Data from all years in the period 2007-2016 } & \multicolumn{2}{|c|}{ Excluding data from 2012} \\
\hline & $\begin{array}{c}\text { Cumulative leasing } \\
\text { in Agriculture, } \\
\text { forestry and } \\
\text { fisheries sector }\end{array}$ & $\begin{array}{c}\text { Cumulative leasing } \\
\text { in Agricultural } \\
\text { equipment }\end{array}$ & $\begin{array}{l}\text { Cumulative leasing } \\
\text { in Agriculture, } \\
\text { forestry and } \\
\text { fisheries sector }\end{array}$ & $\begin{array}{l}\text { Cumulative leasing in } \\
\text { Agricultural equipment }\end{array}$ \\
\hline p-value & 0.00503 & 0.00449 & 0.00113 & 0.00167 \\
\hline $\begin{array}{l}\text { Determination } \\
\text { coefficient } \mathrm{R}^{2}\end{array}$ & 0.647 & 0.656 & 0.8 & 0.777 \\
\hline
\end{tabular}

Source: Authors' research

By analyzing the obtained results and p-values from Table 4, it can be concluded that the dependence of the change in Intermediate consumption on Cumulative leasing in Agriculture, forestry and fisheries sector and on Cumulative leasing in Agricultural equipment is subject to the law of positive linear regression. In addition, a slightly more reliable linear dependence is obtained if the analysis excludes data from the year when climatic conditions were predominantly bad for agricultural output (2012), than when they are used in the analysis.

In fact, p-values excluding data from 2012 equal 0.00113, 0.00167, while p-values including data from 2012 are $0.00503,0.00449$. In both cases, linear regression dependence describes changes with a probability higher than 0.99 , which is absolutely acceptable.

Also, both with and without data from 2012, a significant impact of Cumulative leasing in agriculture on the change in Intermediate consumption is detected. Including data from 2012, about $65 \%$ of the change in Intermediate consumption is described by the obtained positive linear regression dependence, since the determination coefficients $\mathrm{R}^{2}$ are equal to 0.647 and 0.656 . On the other hand, excluding data from 2012, about $79 \%$ of the change in Intermediate consumption is described by the obtained positive linear regression dependence, with the determination coefficients $\mathrm{R}^{2}$ being 0.8 and 0.777 .

The impact of cumulative leasing in agriculture on the volume of realized profit before taxation and subsidies was analyzed by means of its impact on Gross value added, and on the volume of realized profits after taxation and subsidies by means of impact on Factor Income in the period 2007-2016. In that period, Gross value added increased by $25.39 \%$ and Factor income by $33.45 \%$. Table 5 shows the parameters of the regression analysis for Gross Value Added and Factor Income. 
Table 5. The parameters of the regression analysis for Gross Value Added and Factor Income

\begin{tabular}{|c|c|c|c|c|c|c|c|c|}
\hline \multirow[b]{3}{*}{$\begin{array}{c}\text { The } \\
\text { parameters } \\
\text { of regression } \\
\text { analysis }\end{array}$} & \multicolumn{4}{|c|}{ Gross value added } & \multicolumn{4}{|c|}{ Factor income } \\
\hline & \multicolumn{2}{|c|}{\begin{tabular}{|c|}
$\begin{array}{c}\text { Data from all years in the } \\
\text { period 2007-2016. }\end{array}$ \\
\end{tabular}} & \multicolumn{2}{|c|}{ Excluding data from 2012} & \multicolumn{2}{|c|}{$\begin{array}{l}\text { Data from all years in the } \\
\text { period 2007-2016 }\end{array}$} & \multicolumn{2}{|c|}{ Excluding data from 2012} \\
\hline & $\begin{array}{c}\text { Cumulative } \\
\text { leasing in } \\
\text { Agriculture, } \\
\text { forestry and } \\
\text { fisheries } \\
\text { sector } \\
\end{array}$ & $\begin{array}{l}\text { Cumulative } \\
\text { leasing in } \\
\text { Agricultural } \\
\text { equipment }\end{array}$ & $\begin{array}{c}\text { Cumulative } \\
\text { leasing into } \\
\text { Agriculture, } \\
\text { forestry and } \\
\text { fisheries } \\
\text { sector } \\
\end{array}$ & $\begin{array}{l}\text { Cumulative } \\
\text { leasing in } \\
\text { Agricultural } \\
\text { equipment }\end{array}$ & $\begin{array}{l}\text { Cumulative } \\
\text { leasing in } \\
\text { Agriculture, } \\
\text { forestry and } \\
\text { fisheries } \\
\text { sector } \\
\end{array}$ & $\begin{array}{l}\text { Cumulative } \\
\text { leasing in } \\
\text { Agricultural } \\
\text { equipment }\end{array}$ & $\begin{array}{l}\text { Cumulative } \\
\text { leasing in } \\
\text { Agriculture, } \\
\text { forestry and } \\
\text { fisheries } \\
\text { sector } \\
\end{array}$ & $\begin{array}{c}\text { Cumulative } \\
\text { leasing in } \\
\text { Agricultural } \\
\text { equipment }\end{array}$ \\
\hline $\mathrm{p}$-value & 0.396 & 0.339 & 0.0371 & 0.0387 & 0.112 & 0.083 & 0.0273 & 0.0227 \\
\hline $\begin{array}{l}\text { Determination } \\
\text { coefficient } \mathrm{R}^{2}\end{array}$ & 0.0915 & 0.115 & 0.485 & 0.48 & 0.284 & 0.329 & 0.525 & 0.547 \\
\hline
\end{tabular}

Source: Authors' research

Analyzing the obtained results and p-values from Table 5 it is concluded that the dependence of the change in the Gross value added and Factor income on Cumulative leasing in Agriculture, forestry and fisheries sector and on Cumulative leasing in Agricultural equipment are subject to the law of positive linear regression only for the data from 2012. Then the $\mathrm{p}$ values equal $0.0371,0.0387,0.0273,0.0227$. However, this linear dependence of the change is not significant, since the determination coefficients $\mathrm{R}^{2}$ are not large $(0.485,0.4,0.525,0.547)$.

If the data from 2012 are included, the existence of a linear regression dependence of the change in Gross value added and Factor income on Cumulative leasing in Agriculture, forestry and fisheries sector and on Cumulative leasing in Agricultural equipment is not detected, as p-values are inadmissibly high $(0.396,0.339,0.112,0.083)$.

\section{Conclusion}

The placement of leasing in agriculture from 2006 to 2017 affected the volume of agricultural goods production. This impact is, to a greater or lesser extent, positively linearly correlated with agricultural outputs. In absolute terms, it is not large, because leasing placement in agriculture at the annual level ranges from 3 to $5 \%$ of the Intermediate annual consumption in agriculture. Also, the total ten-year cumulative leasing placement (2006-2015) in Agriculture, forestry and fisheries sector is 29.13\% of the Intermediate annual consumption only in 2010. For the placement in Agricultural equipment, this percentage is $24.10 \%$.

Absolute values of agricultural outputs are mostly determined by agricultural capacities in the Republic of Serbia and climatic conditions during the current year. The analysis has shown that the impact of cumulative leasing on agricultural output is about ten times lower than the impact of climate conditions and agricultural potential of the Republic of Serbia.

The volume of agricultural production in the period 2007-2016, expressed by means of the Output of agricultural industry and Total agricultural goods output, individually, is in positive linear correlation with Cumulative leasing in agriculture in the period 2006-2015. Even the bad climatic conditions in 2012 did not affect the form of dependence, but only the size of the impact. 
In fact, in the case when the data from 2012 were used, when the climatic conditions were predominantly bad, about $40 \%$ of the change in the Output of agricultural industry and about $35 \%$ of the change in the Total agricultural goods output was described by positive linear-regression dependencies.

When data from the mentioned year were not used, about $76.5 \%$ of the change in the Output of agricultural industry and about $66 \%$ of the change in the total agricultural goods output was described by positive linear-regression dependencies.

This is another indicator of the strong impact of bad annual climate conditions on the volume of annual agricultural production.

The volume of costs during agricultural production in the period 2007-2016 expressed through the Intermediate consumption is also positively linearly correlated with the cumulative leasing placement in agriculture in the period 2006-2015, regardless of the bad climatic conditions in 2012.

If data from 2012 are included, about $65 \%$ of the change of Intermediate consumption was described by the obtained positive linear-regression dependence. On the other hand, without data from 2012, about 79\% of the change of Intermediate consumption was described by the obtained positive linear-regression dependence. This proves that poor climatic conditions from 2012 did not significantly affect further investment in agriculture.

Bad climatic conditions from 2012 completely excluded in the impact of cumulative leasing placement in agriculture on the volume of realized profit. For that year no correlation dependence of either Gross value added (the measure of the volume of realized profit without taxes and subsidies) or Factor income (the measure of the volume of realized profit with taxes and subsidies) on cumulative leasing placement in agriculture was detected.

The analysis of the data from a bad climatic year has shown that the linear correlation between Gross value added and cumulative leasing in agriculture, as well as between Factor income and cumulative leasing in agriculture, exists but is not dominant. This is a good indicator of the strong impact of climatic conditions on the volume of realized profit in agriculture.

Therefore, a general conclusion is that leasing placement in the agricultural sector in the period 2006-2015had a positive impact on the growth of the volume of agricultural production in the period 2007-2016, as well as the increase in Intermediate consumption during the agricultural production process, while it had no noticeable impact on the volume of realized profit in agriculture in that period. In absolute terms this impact is not huge, since the agricultural production capacity of the Republic of Serbia and the annual climatic conditions are dominant for agricultural outputs, and it ranges up to $10 \%$ of the total agricultural output. 


\section{Acknowledgements}

Paper work is a part of the project III 46006: „Sustainable agriculture and rural development in the function of Republic of Serbia strategic goals achievement within the Danube region“, financed by the Ministry of Education and Science of Republic of Serbia.

\section{Conflict of interests}

The authors declare no conflict of interest.

\section{References}

1. Bogdanović, M. (1967). Economics of agriculture of Yugoslavia. Belgrade [in Serbian: Bogdanović, M. (1967), Ekonomika poljoprivrede Jugoslavije. Savremena administracija, Beograd].

2. Grujić, B. (2017). Financing of Agriculture of the Republic of Serbia from traditional to new models, doctoral dissertation, University John Naisbitt, Faculty for business studies Belgrade [in Serbian: Grujić, B. (2017), Finansiranje poljoprivrede Republike Srbije od tradicionalnih ka novim modelima, doktorska disertacija, Univerzitet Džon Nezbit, Fakultet za poslovne studije Beograd].

3. Grujić, B., \& Ljubić, M. (2016). The Contribution of the Agrarian Budget to Rural Development in the Republic of Serbia - Case Study, in Monography Rural Communities in the Global Economy - Beyond the Classical Rural Economy Paradigms, Nova Science Publishers, New York, USA, 253-278.

4. National bank of Serbia. Financial leasing sector in Serbia, Fourth Quarter Report for period 2006 - 2016, Belgrade, https://www.nbs.rs/internet/ english/57/57 3/index.html (October 28, 2017)

5. Paraušić, V. \& Cvijanović, D. (2007). Serbian agriculture - programmes of credit support by the state and commercial banks between 2004-2007. Economic Annals, No. 174-175, Faculty of economics, Belgrade, 186-207. [in Serbian: Paraušić, V., Cvijanović, D. (2007), Poljoprivreda Srbije-programi kreditne podrške države i komercijalnih banaka u periodu 2004-2007, Časopis Ekonomski anali, broj 174-175, Ekonomski fakultet Beograd, str. 186-207.

6. Radović, G. (2014). Financing agriculture in the Republic of Serbia. Endowment Andrejević, Belgrade [in Serbian: Radović, G. (2014), Finansiranje poljoprivrede u Republici Srbiji, Zadužbina Andrejević, Beograd].

7. Statistical Office of the Republic of Serbia (2017), Economic accounts for agriculture in the Republic of Serbia, 2007-2016, N 101, Belgrade.

8. Brealey, R., Myers, S. \& Alan J., (2001), Marcus Fundamentals of Corporate, Finance McGraw-Hill/Irwin.

9. RS Official Gazette, Nos 55/2003, 61/2005, 31/2011 and 99/2011. Law on Financial Leasing [in Serbian: Sl. Glasnik RS, br. 55/2003, 61/2005, 31/2011 i 99/2011-dr. zakoni, Zakon o finansijskom lizingu] 